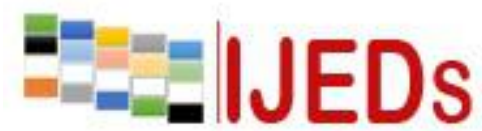

http://ijeds.ppj.unp.ac.id/index.php/IJEDS

\title{
DEVELOPMENT OF LOCAL INSTRUCTION THEORY TOPICS LOWEST COMMON MULTIPLE AND GREATEST COMMON FACTORBASED ON REALISTIC MATHEMATICS EDUCATION IN PRIMARY SCHOOLS
}

\author{
*Ditria Yulianti', Ahmad Fauzan ${ }^{2}$ \\ ${ }^{1}$ College Student Primary Education. FIP Universitas Negeri Padang, Indonesia \\ ${ }^{2}$ Mathematics lecture, FMIPA Universitas Negeri Padang, Indonesia \\ E-mail: ditriayulianti@gmail.com
}

*Corresponding Author, Received: November 12, 2018, Revised: December 10, 2018, Accepted: December 21, 2018

\begin{abstract}
This study discusses developing a mathematical education (RME) based local theory (LIT) that is valid, practical, and effective on the topic of the lowest common multiple and greatest commonfactorin grade $\mathrm{V}$ of elementary school. The research method used is the type of research design Gravemeijer and Cobb (2013). This research was conducted in three phases, namely conducting experiments, experimenting in class, and conducting a retrospective analysis. Data was collected using document analysis, observation, interviews, field notes, tests, and questionnaires. The collected data was analyzed qualitatively and quantitatively. Based on the research that has been done, LIT has been approved which is valid, practical, and effective for students' mathematical literacy abilities. Students can solve the problems ofLCM and GCF with various activities, namely finding multiples and multiples of fellowship, finding factors and factors of fellowship then resolving problems related to daily life.
\end{abstract}

Keywords: LIT, RME, LCM, CGF.

\section{INTRODUCTION}

Mathematics is one of the subjects taught in Elementary School (SD). Many people view mathematics as the most difficult field of study. Even so, everyone must learn it because it is a means of solving problems in everyday life (Tobondo, 2014). For example, in trading (buying and selling) and measuring land area calculations using mathematics, house numbers, car numbers, and telephone numbers using numbers, and in computer science there are computer programs that use basic mathematical concepts 


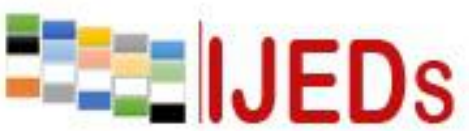

http://ijeds.ppj.unp.ac.id/index.php/IJEDS

to solve problems and problems. about mathematics (Yuniati, 2012). Therefore mastery of mathematics is needed for all students so that it can be applied in their daily lives. Lowest common multiple and greatest commonfactoris one of the topics studied in the fifth grade mathematics subject in elementary school. In Yudhi (2017) LCM and CGF are algebraic objects that talk about the concept of numbers. The basic concepts of LCM and CGF are factors and multiples of a number. Students must understand the topic of LCM and CGF because this topic is often used in daily life such as buying goods or food, determining holiday schedules, can also be used to calculate planetary orbits and other things.

LCM and CGF learning in elementary schools tend not to use the student center approach. This is evidenced by teacher-dominated learning. The topics presented support conventional and mechanistic teaching styles, namely giving rules indirectly to be memorized, remembered, and applied. In Camli's research (2009) LCM and CGF were one of the topics of study in Turkey which faced students having difficulty in understanding. Despite the fact that learners know the concepts of LCM and CGF, they are not good at using the concepts given and visualizing problems in their minds.

The concepts of factors, multiples, LCM and CGF are often very basic, but not in full. Examples of determining LCM and CGF tend to use one method, namely the concept of factor tree (prime factorization) and table, while the emergence of this concept is not examined so that the methods for determining the LCM and CGF only follow the usual methods in the textbook (Desriyati, 2015). In line with that, in the study of Marzuki (2015) that the completion of LCM and CGF topics was still very procedural, namely by using factor trees or prime factorization and learning outcomes on LCM and CGF topics were not optimal.

In addition to the factors of teachers and students, learning is also influenced by the learning tools used. Based on the analysis conducted on teacher books, student books and class V student worksheets (LKPD) used in the School, it was found that the LCM and CGF topic presentation was not optimal. In Yudhi's research (2017) Student worksheets (LKPD) and student books used in schools have not provided opportunities for students to construct their own knowledge. 


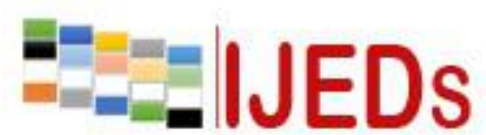

http://ijeds.ppj.unp.ac.id/index.php/IJEDS
International Journal of Educational Dynamics

Vol. 1 No. 1 (pp. 222-235) December 2018

p_ISSN 2655-4852

e_ISSN 2655-5093

In addition to not being given LCM and CGF material or concepts, the questions given are also less varied and have not been linked to real problems that will affect students' mathematical thinking skills. According to Sumartini (2015) said that mathematical reasoning ability is a habit of the brain as well as other habits that must be developed consistently using various kinds of contexts, recognizing reasoning and proof are fundamental aspects in mathematics. With mathematical reasoning, students can put forward suspicions and then compile evidence and manipulate mathematical problems and draw conclusions correctly and precisely.

To overcome this system of mathematics teaching errors, one of the learning approaches created specifically for mathematics learning is Realistic Mathematics Education (RME). Three principles of RME are guided reinvention and progressive mathematizing, didactical phenomenology, and self developed models (Gravemeijer, 1994). The three principles are guided discovery, learning starts from a context that is close to students, and problem solving by students themselves. These three principles can make students active and challenged in learning mathematics. An approach that can train students to actively build their understanding by empowering their prior knowledge, and can use the concepts they have to solve problems related to daily life.

According to Cobb (2008) RME learning can develop important mathematical ideas through problems that challenge and relate to the daily lives of students. One of the principles of RME learning is the principle of guided discovery that emphasizes the opportunity for students to discover mathematical concepts themselves through solving contextual problems. Therefore, the teacher must be able to map the learning path to find the concept of mathematics with the RME approach. Thus the RME approach can have a good impact on students' mathematical reasoning abilities. The flow of learning is a learning path that contains ways to teach a mathematical topic, activities in solving contextual questions, predictions of students' answers in solving contextual problems, and anticipating theories about predictions of student answers. The learning flow developed is contained in HLT. Learning flow based on learning trajectory is known as hypotetical learning trajectory (HLT) which will eventually become Local Intructional Theory (LIT) Local Instruction Theory (LIT) is a theory of the learning process that describes learning trajectories on a particular topic with a set of activities that support it 


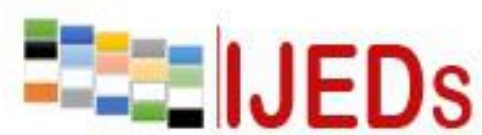

http://ijeds.ppj.unp.ac.id/index.php/IJEDS

(Gravemeijer and Eerde, 2009). LIT' of LCM and CGF topics are designed with the RME approach, so that learning uses real problems and is close to the life of the students. The design is made in three stages, namely the preparation phase (experiment design), conducting phase (conducting the experiment) and the retrospective analysis phase (the retrospective analysis).

\section{METHOD}

The type of research used is development research approach. The development model used is research design type Gravemeijer and Cobb (2013). The design of the study consisted of three phases, namely preparing for the experiment, experimenting in the classroom, and conducting retrospective analysis (Gravemeijer and Cobb, 2013). The activity in developing Local Instructional Theory (LIT) with its initial form is HLT, starting with doing a thought experiment, thinking about the learning path that students will pass in understanding a concept or topic. By reflecting on the results of the learning process after the results of the thought experiments were tested, the researchers proceeded to the next thought experiment. In the long run, parts of the thought experiment will be connected to one another. This activity can be seen as a cyclical process, as shown in the following figure:

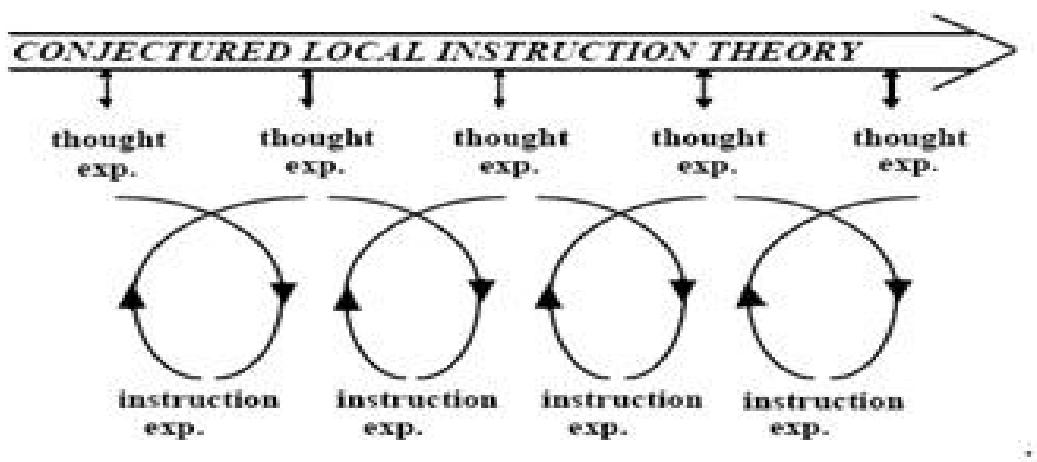

Figure1. Learning Experiments Gravemeijer \& Cobb (2013) 


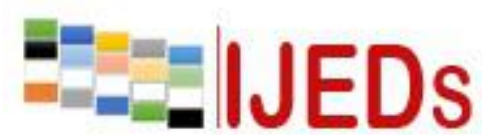

http://ijeds.ppj.unp.ac.id/index.php/IJEDS
International Journal of Educational Dynamics

Vol. 1 No. 1 (pp. 222-235) December 2018

p_ISSN 2655-4852

e_ISSN 2655-5093

This cyclical process cumulatively will lead to the development of theories about how to design and teach certain mathematical topics, called "local imtructional theory" (Fauzan, 2006). The procedure of research design development research types Gravemeijer and Cobb consists of three phases namely preparing for the experiment, experimenting in the classroom, and conducting retrospective analysis (Gravemeijer \& Cobb, 2013).

\section{Preparing for The Experiment Phase}

In this phase various activities are carried out, namely needs and context analysis, literature review, product design and formative evaluation with the aim of designing products that want to be produced such as LIT, RPP and LKPD.

\section{Experimenting in the Classroom Phase}

The activities carried out in this phase are implementing products that have been validated by the validator which is a continuation of Tessmer's formative evaluation steps, namely one to one, small group and field tests. In this phase the researcher does not carry out one to one steps because of the limited time he has. If doing the one to one step the topic of LCM and CGF will be far behind the learning schedule at school, this also takes into consideration that in the small group step it also requires several meetings. In this phase, the achievement of HLT is the basis of the success of the product. If during the trial in class, predictions of anticipation that have been made are not reached, then do the thought experiment and instruction experiment again until students reach the expected goals.

\section{Conductng Retrospective Analyses Phase}

The third phase is a retrospective analysis, which goes hand in hand with the experimenting phase in the classroom. This phase is very instrumental in pilot activities during small groups and field tests. The thing that was done in this phase was evaluating whether the planned HLT was running as expected. The learning trajectory plan used in the retrospective analysis is a guideline and main reference in answering the research problem formulation. The main objective at this stage is to contribute to the development of HLT in supporting students' understanding of the topic being studied. The role of HLT in this stage is to become a guide in determining the focus of analysis in research. 


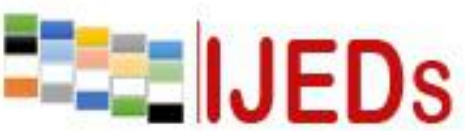

http://ijeds.ppj.unp.ac.id/index.php/IJEDS

The process of analysis is not only on the factors that support the success of learning but also on some of the alleged learning that does not get a response from students. If students do not get a response, the teacher can replace it by using probing questions. The explanation obtained is used to draw conclusions and answer research questions. Shingga, in the end HLT which was carried out until the final meeting in the field test step and no revisions were made, became a product called Local Instuctional Theory (LIT).

\section{RESULTS AND DISCUSSION}

\section{Phase Preparing for the Experiment}

The results of the curriculum analysis found that the topics of LCM and CGF learned in class V students were using factor trees without students knowing the concept. In this case, the expected achievement is to be able to use various ways of solving to solve problems related to LCM and CGF. Then, the results of the analysis of students found that fifth grade students at SDN 05 Air Tawar Barat and SDN 09 Air Tawar Barat as the subject of this study had a preference for blue LKPD, images related to nature and cartoons, buying bakso bakso and cold drinks, and also have the habit of swimming and reading. Meanwhile, the results of environmental analysis found that most parents work as traders, teachers, and fishermen.

The results of a literature review of RME found that RME learning emphasized three main principles, namely guided reinvention through progressive mathematical, didactic phenomenology, and self-developed models or emerging models. In the principle of reinvention, students are given the opportunity to experience a process that resembles the mathematics made. With regard to this principle, the learning path must be mapped by allowing students to find their own mathematics. Then, Phenomenology of Didactics is related to the development of learning which must give students contextual problems taken from real and meaningful phenomena. Meanwhile, self-developed models play an important role in bridging the gap between informal knowledge and formal knowledge.

The learning process involves horizontal mathematics and vertical mathematics. Students have the opportunity to solve contextual problems by using 


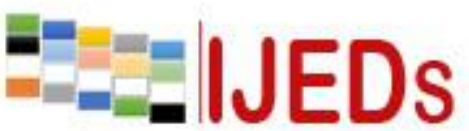

http://ijeds.ppj.unp.ac.id/index.php/IJEDS
International Journal of Educational Dynamics

Vol. 1 No. 1 (pp. 222-235) December 2018

p_ISSN 2655-4852

e_ISSN 2655-5093

informal language as horizontal mathematics. After students experience a similar process in some time, informal language develops into a more formal or standard language. In the end, students can use mathematical algorithms. This is called vertical mathematics. The four objectives are to be able to find and use algorithms that are carried out with a series of ongoing activities. Exploring learning objectives, asking questions about contextual problems, identifying questions and making answers, solving problems in the LKPD, responding to problem solving by other groups, discussing and evaluating.

Products that have been designed and carried out by self-evaluation, followed by three validation experts, namely content validators, language validators, and graphic validators to produce valid products. The results of content validators that are generally owned by products are B values with little improvement. Suitability is the use of problems and predictions of activities carried out by students. Then, the language validator also gives a B value to the product. Suggestions are given font usage, font size, and sentence suitability. Meanwhile, the product value is graphically B. The information provided is the suitability of the paper size and the clarity of the image and the reference of the image used.

\section{Phase Experimenting in the Classroom and Phase Conducting Retrospective Analyzes}

The product is valid, followed by conducting small group trials and field tests. The small group trial phase was carried out on 6 fifth grade students of SDN 09 Air Tawar Barat. The trial was conducted outside the teaching and learning hours. Small group testing starts from 19-23 November 2018. The results are found, for 4 meetings there are several forms of answers written by students. On the first day, students are expected to be able to use multiplication repetitions to find multiples and multiples of fellowship. With 2 activities given, there is horizontal mathematics into vertical mathematics. This is found in the form of answers written by students, although there are still some students who still have not used multiples for multiples of one and two numbers for activity 2. However, student answers to Activities 1 and 2 have different forms or answer patterns. In activity 1, students still use summation, but in activity 2 uses multiplication to find multiples of a number. 


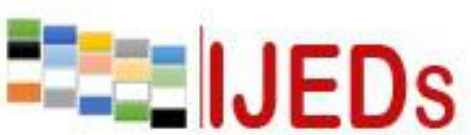

http://ijeds.ppj.unp.ac.id/index.php/IJEDS

On the second day, students are expected to be able to use multiples and clerical associations to solve problems related to LCM using various methods. In this case, the concept of completion that has been used before becomes horizontal math students to complete activity 1 and activity 2 LKPD 2. Various forms of answers are produced until students can use multiples and multiple connections both by using tables, factor trees even though students cannot use them. Based on the answers found in Activity 1, students use classes in sequence, but also find students who only use the factor tree to find the LCM of a number. Students can shorten the answer to the solution correctly. While in Activity 2, several students have tables.

On the third day, students are expected to solve the problem to find the biggest factors and factors of fellowship. The results of two activities are given that students use numbers that can divide up a number. This is found in many activities 1 . While activity 2 , some students have reached vertical mathematics. On the last day, previous learning experience is a provision for students to reach the top of the learning path that is implemented, namely solving problems related to CGF in everyday life. In Activity 1, students use fellowship factors and factors. However, in Activity 1, students were found using a factor tree form, even though there was an error in determining the prime factorization of the number. While activity 2 , some students change the shape of the solution as before to form a standard algorithm. The results found in the small group trial became an improvement material for implementing the product in the actual class trials. Various improvements were made, namely predictions of problem solving activities to be carried out by students and anticipations to be made through probing questions.

\section{Day 1. Find crosses and multiples of fellowship}

During activity 1 at the LKPD, there were students who were just silent and did not understand what was being done to solve it. At that time, the teacher gave questions to students, such as the conversation below. The question is the anticipation that the teacher has prepared to guide students during learning activities. There are several forms of answers that have not been used to find multiples and creations of fellowship. However, in general students use additional repetitive sequences.In activity 
http://ijeds.ppj.unp.ac.id/index.php/IJEDS

1 , students solve the problem by using ten repetitive additions. Then, the teacher provides guidance through a series of questions, as below

\begin{tabular}{|c|c|}
\hline Student Answers Prediction & Teacher's anticipation \\
\hline $\begin{array}{l}\text { Students cannot translate real world situations into } \\
\text { mathematical experiences. }\end{array}$ & $\begin{array}{l}\text { The teacher gives probing questions in the form } \\
\text { of: } \\
\text { How many children are there in the problem } \\
\text { above? } \\
\text { One grilled meatball stick, how many bakso } \\
\text { meatballs? } \\
\text { If you have a playdough toy meatball stick from } \\
\text { this plasticine, what can you do with this? }\end{array}$ \\
\hline $\begin{array}{l}\text { Students use plasticine and still do summation } \\
\text { counting operations repeatedly, as follows. }\end{array}$ & $\begin{array}{l}\text { The teacher gives probing questions in the form } \\
\text { of: } \\
\text { Do we need to add like this? } \\
\text { If later for example Ani buys } 100 \text { meatball sticks } \\
\text { do we have to add } 4 \text { to } 100 \text { times? }\end{array}$ \\
\hline $\begin{array}{l}\text { Students count many eggs of each child using the } \\
\text { multiplication form as follows. }\end{array}$ & $\begin{array}{l}\text { The teacher gives probing questions in the form } \\
\text { of: } \\
\text { How many times is the amount of bakso baked } \\
\text { each of them? Come on write down the results } \\
\text { in sequence. } \\
\text { What is the pattern? } \\
\text { What number of grilled meatballs for each child } \\
\text { is a multiple? }\end{array}$ \\
\hline
\end{tabular}

\section{Day 2. Complete LCM issues related to daily life}

On the second day, there were two activities completed by students. The expected final result is that students can solve problems related to LCM and to solve contextual problems regarding multiplication. The tool used to help students solve the problem is grilled meatballs made from plasticine. However, on that day, students chose not to use the tools provided in solving problems. In activity 1, students solve problems using multiples and multiples of fellowships using tables, and factor trees. Then, the teacher provides guidance through a series of questions, as below: 
http://ijeds.ppj.unp.ac.id/index.php/IJEDS

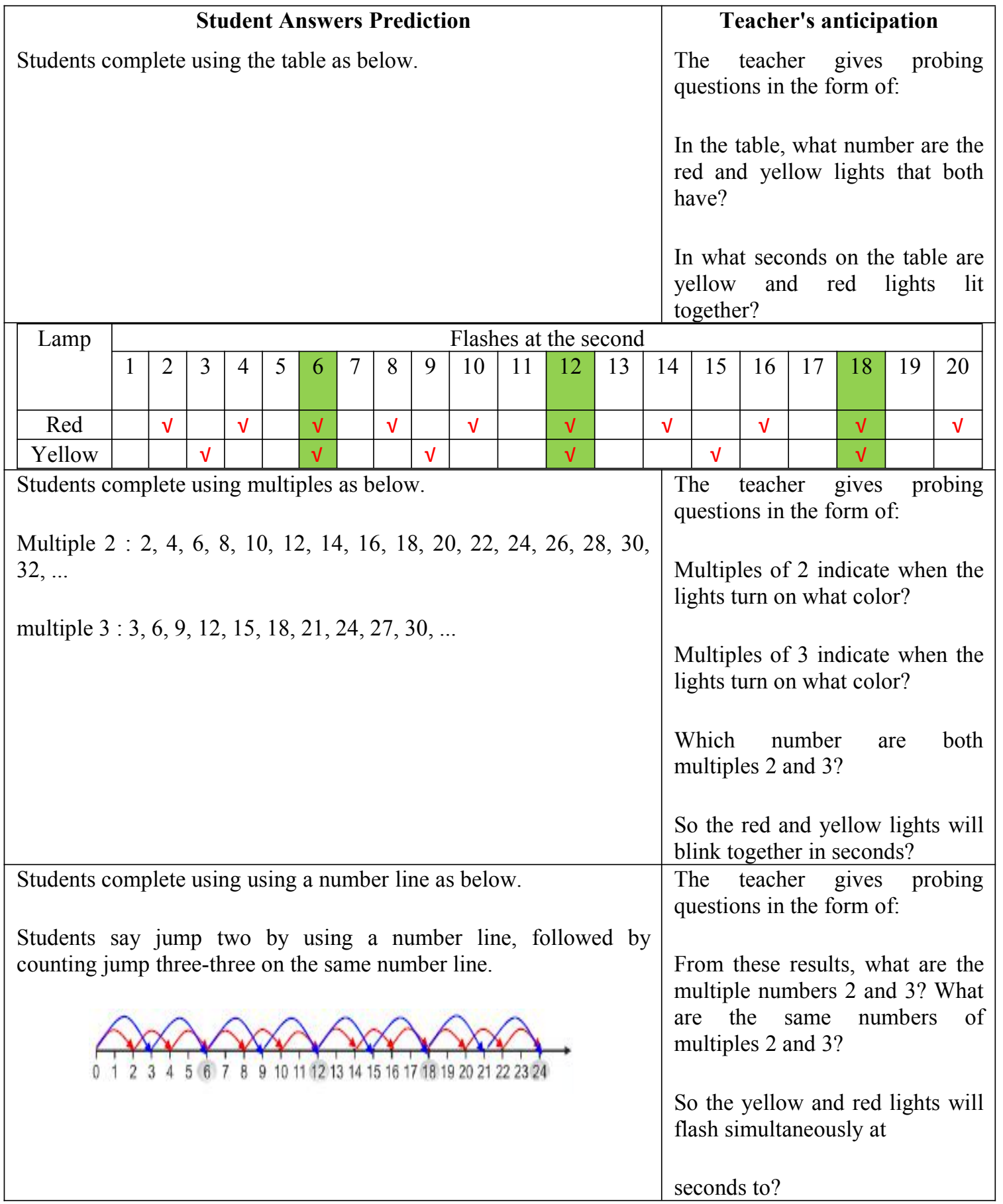

In the 2 LKPD activities, students have begun to use various ways to solve problems, although there are still some students who still use using repeated additions. 


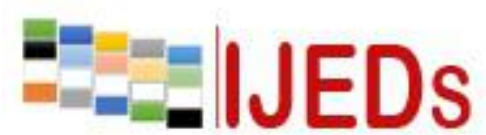

http://ijeds.ppj.unp.ac.id/index.php/IJEDS

\section{Day 3. Find fellowship factors and factors}

On the third day, students are expected to be able to find the factors and factors of sequencing, namely numbers that can divide up a number. The results found that students used factor and table trees to find them When students use these methods, the teacher guides students with questions, as below.

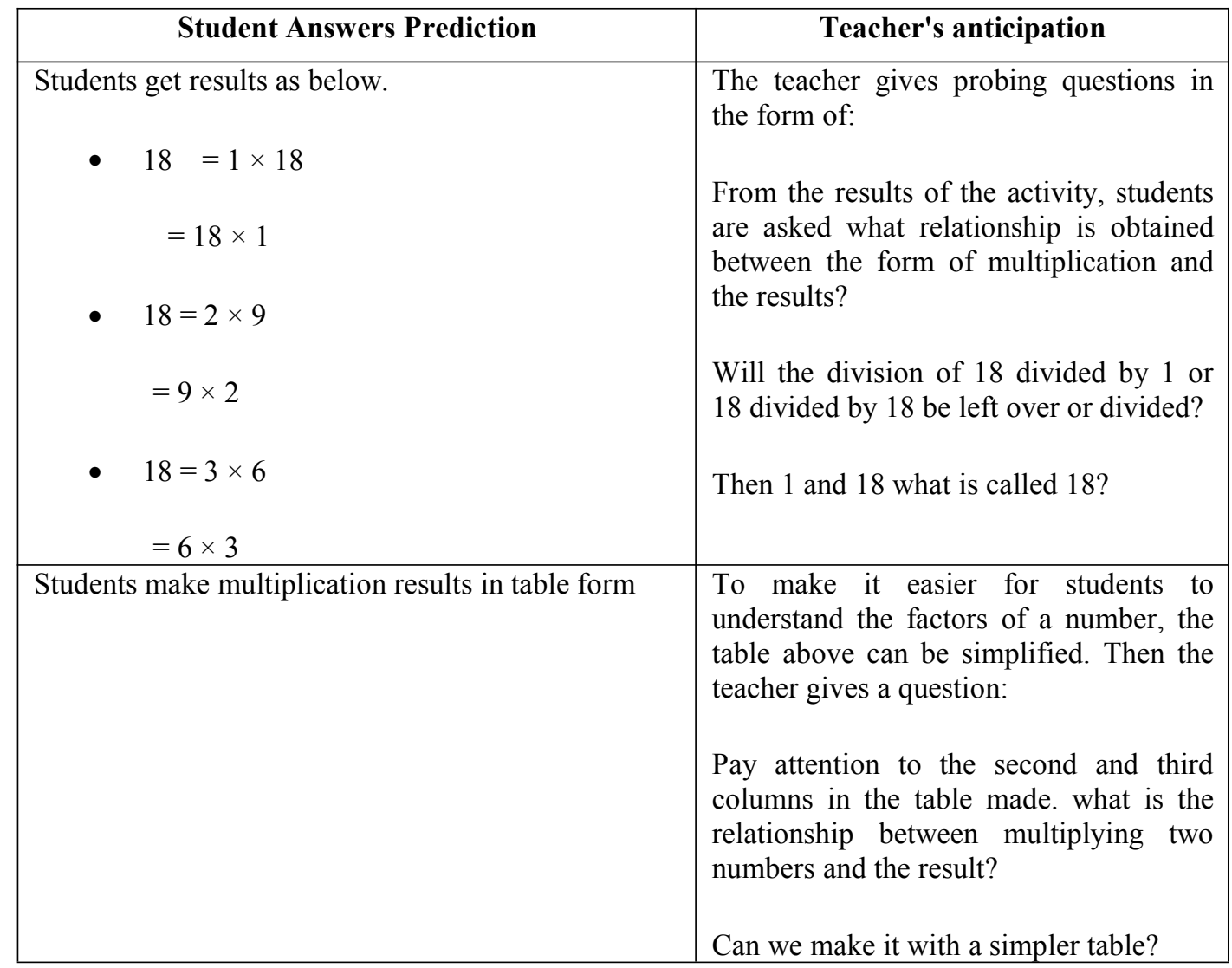

\section{Day 4. Resolve issues related to CGF}

Many students like to use factor trees to solve problems given on the fourth day. This is overcome by giving questions, as below. 


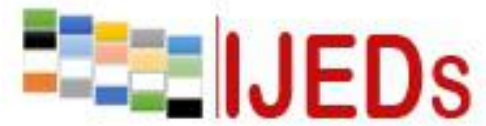

http://ijeds.ppj.unp.ac.id/index.php/IJEDS

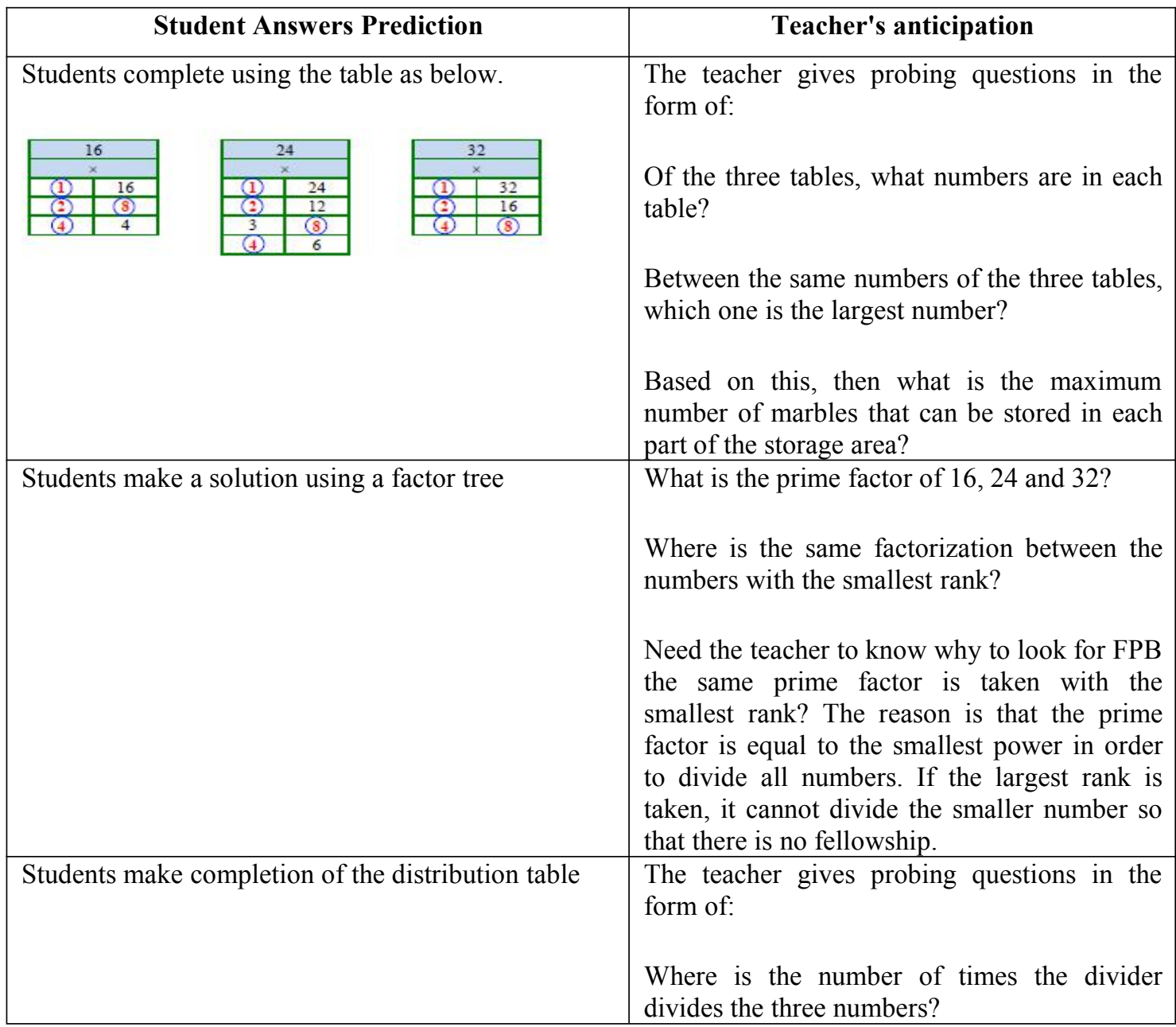

Based on the students' activities and answer findings, it can be described the form of change in answers of students who initially only knew how to solve LCM problems and CGF only with a factor tree, now students can know the LCM and CGF concepts themselves so they can solve various ways and can practice mathematical reasoning skills students. The main results of this study indicate that through contextual problem solving activities in each learning pathway, students can find multiples and multiples of fellowships, complete problems related to the LCM, find fellowship factors and factors and resolve problems related to the CGF. With the three main principles of RME that form the basis of learning activities, the practicality of learning carried out shows very practical criteria with a value of $85 \%$. Meanwhile, product effectiveness has a positive impact on students' mathematical literacy abilities. This was reviewed from 


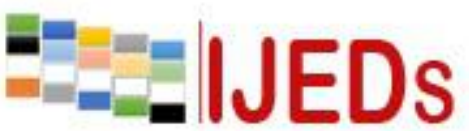

http://ijeds.ppj.unp.ac.id/index.php/IJEDS
International Journal of Educational Dynamics

Vol. 1 No. 1 (pp. 222-235) December 2018

p_ISSN 2655-4852

e_ISSN 2655-5093

the evaluation results at the end of each meeting which showed $81 \%$ of students had mathematical reasoning abilities with very good criteria.

\section{CONCLUSION}

Local Instruction Theory developed on lowest common multiple and greatest commonfactor topics using realistic mathematics education in fifth grade students of elementary school fulfills valid, practical, and effective criteria. Valid criteria are reflected in the results of validation assessed by experts. The practical criteria are reflected in the assessment of the learning process carried out through observation sheets and questionnaires, and students can work according to the hypothesis. Meanwhile, the effective criteria are reflected by being able to improve the mathematical reasoning abilityof grade fifth students in elementary school.

\section{REFERENCES}

Camli, H and Bintars, J. 2009. Mathematical Problem Solving and computers: Investigation of the Effect of Computer aided instruction in solving lowest common multiple and greatest common factor problems. International Journal of Human Sciences. Volume: 6 Issue: 2 Year: 2009 ISSN 1303-5134.

Cobb, Paul, Qing Zhao and Jana Visnovska. 2008. Learning from and Adapting the Theory of Realistic Mathematics education. Presses universitaires de Rennes, DOI: 10.4000 .

Desriyati, Welly, Mashadi and Sri Gemawati. 2015. Cara Lain Menentukan LCM dan CGF. Jurnal Sains Matematika dan Statistika, Vol. I, No. 1, Januari 2015. ISSN $2460-4542$

Fauzan, A. 2002. Applying Realistics Mathematics Education (rme) in Theaching Geometry in Indonesian Primary Schools. Den Haag: CIP Gegevens Koninklijke Bibliotheek

Fauzan, A., Plomp, T., and Gravemeijer, K. 2013. The Development of an Rme-Based Geometry Course for Indonesian Primary Schools. In T. Plomp, \& N. Nieveen (Eds.), Educational design research.

Gravemeijer, K.P.E. 1994. Developing Realistic Mathematics Education, Culenborg: Technipress.

Gravemeijer and Cobb. 2006. Educational Design Research: Design Research from a Learning Design Perspective (Page. 45-85). UK: Routledge.

Gravemeijer, K., and Cobb, P. 2013. Design Research from the Learning Design Perspective. In J. V. Akker, B. Bannan, A. E. Kelly, N. Nieveen, \& T. Plomp, Educational Design Research (pp. 72-113). Enschede: Netherlands Institute for Curriculum Development (SLO). 
http://ijeds.ppj.unp.ac.id/index.php/IJEDS

Marzuki. 2015. Prestasi Belajar Kelipatan Persekutuan Terkecil Dan Faktor Persekutuan Terbesar Dengan Mengunakan Alat Bantu Dekak-Dekak Pada Peserta didik Kelas IV Sd Negeri 4 Bireuen. JUPENDAS, ISSN 2355-3650, Vol. 2, No. 1

Rangkuti, A. N. 2015. Pengembangan Alur Pembelajaran Topik Pecahan di Sekolah Dasar dengan Pendekatan Pendidikan Matematika Realistik. Padang: Universitas Negeri Padang.

Simon, M. A. 1995. Reconstructing Mathematics Pedagogy From A Condtructivist Perspective. Journal of Research in Mathematics Education, XXVI(2), 114-145.

Tobondo, Yunda Victorina and Yuni Vonti Ria Sinaga. 2014. Identifikasi dan analisis kesulitan peserta didik kelas IV dalam menyelesaikan soal cerita topik pecahan, CGF, dan LCM.Prosiding seminarnasional sains dan pendidikan sains IX, fakultas sains dan matematika.UKSW.Salatiga, 21 juni 2014. Vol 5 no 1, issn; 2087-0922

Zakaria, Effandi and Muzakkir Syamaun. 2017. The Effect of Realistic Mathematics Education Approach on Students' Achievement And Attitudes Towards Mathematics. Mathematics Education Trends and Research DOI:10.5899. 